\title{
Soft sediments deformation structures: Implication for draining of Paleo-Kathmandu Lake
}

\author{
Mukunda Raj Paudel \\ Department of Geology, Tri-Chandra Campus, Tribhuvan University, Kathmandu, Nepal \\ Email: mukunda67@gmail.com
}

\begin{abstract}
Kathmandu basin is one of the Quaternary intermontane basins in the central Nepal Himalaya. It is bounded by several faults on both southern and northern margins. The basin is filled with Plio-Pliestocene terrestrial sediments and their characteristics indicate four types of unconsolidated successions within the basin. These are before lake succession, during lake succession, draining stage lake succession and fluvial succession. Late Pleistocene aged Sunakothi Formation crops out along the southern part of the basin. It is a typical fluviolacustrine delta succession that extended from $1390 \mathrm{~m}$ in the southern margin to nearly $1300 \mathrm{~m}$ toward center of the basin. It is composed by poorly consolidated sand, gravelly sand, silt and mud beds. Various soft-sediment deformation structures occur in the formation, especially in fine- to medium -grained sands, silts and mud: load structures, flame structures, clastic dikes (sand dike), disturbed layers, convolute beds, slumps and synsedimentary faulting. The deformation mechanism and driving force for the soft-sediment deformation are related, essentially, to gravitational instability, dewatering, liquefaction and brittle deformation. Field data and the wide lateral extent of the structures as well as regional geological data show that most of the deformation is related to seismicity and the structures are interpreted as seismites. In addition, there have also been experimental studies undertaken by various authors within the different sedimentary basin.

Soft-sediments deformation structure in Kathmandu basin are mainly considered to be part of the initial diagenetic changes of the sediments and include: Slump structure which occurred on the slope like delta-front area, dewatering structures which occurred by the processes of upward escape of water commonly due to loading, load structures which occurred due to density contrasts between sand and underlying wet mud. The existence of seismites in the Sunakothi Formation is evidence of continuing tectonic activity in the study area during the late Pleistocene and is a main factor for draining of the PaleoKathmandu lake water.
\end{abstract}

Keywords: Kathmandu basin, Sunakothi Formation, Soft sediments deformation, Seismite

Received: April 10, 2015

Revision accepted: June 2, 2015

\section{INTRODUCTION}

Kathmandu Valley is located in the Midland of the Lesser Himalaya, surrounded by the Mahabharat range and Shivapuri range of 2500 to $3000 \mathrm{~m}$ above the meen sea level, and elevation of the valley floor is 1300 to $1340 \mathrm{~m}$. This valley has a diameter of 30 to $25 \mathrm{~km}$ and covers about $650 \mathrm{Km}^{2}$ area. More than four million people are living within this small valley but all liquid waste products has been draining through Bagmati river at Katuwal Daha, in the southern most part. It is an only one outlet where river is draining out from valley. This valley was lake since around 1 million to 12,000 year before present.

Tectonics activity since $2.5 \mathrm{Ma}$ of the Lesser Himalaya has caused the damming of the ancient Bagmati river, which was flowing from the north to the south of the Kathmandu Valley (Sakai 2001b). Kathmandu Valley gradually started to change their alluvial-fluvial condition to the marginal lacustrine and proper lacustrine condition before around $1 \mathrm{Ma}$.
Hence, Kathmandu basin sediment is composed by different sedimentary formations, which were deposited over the Kathmandu nappe rocks related to Paleozoic Tethys Himalaya sequence. Each geological unit of the basin-fill sediments has its own geological history. Vertically dipping basement rocks near the southern margin at Katuwal Daha, presence of huge conglomeratic sequence of granitic boulders and their inclination toward the north provide the strong evidences of the northward erosion after damming of an ancient Bagmati river at the southern margin of the basin (Paudel et.al 2004, 2008 , 2014). Such types of the damming and origin of the intermontane sedimentary basins have been recognized in the other region of Himalaya like in India, Pakisthan etc. Even though the causes of the disappearance of this lake are still not clear, there are many thought about the disappearance of this lake. Hence, in this paper, I have briefly explained the types of deformational sedimentary structures and discuss about the causes soft sediment deformation (SSDS) of the draining of an ancient lake on the basis of origin of these structures. 


\section{STUDY AREA}

The Kathmandu Valley measures approximately $30 \mathrm{~km}$ in EW and $25 \mathrm{~km}$ in NS leading to a nearly circular outline. This basin is situated on the Kathmandu Nappe (Stocklin and Bhattarai 1981, Sakai 2001). The rocks of this nappe are ranging in age from Precambrian to Paleozoic of the Kathmandu Complex. According to Stocklin and Bhattari (1981), and Rai (2001) fossiliferous early Paleozoic Tethyan rocks of the Phulchoki Group rest on the metamorphosed Bhimphedi Group. There are small ridges within the basin composed of quartzite, slates and limestone. One prominent ridge runs NWSE across the basin between the Kirtipur and Chobar known as the Kirtipur-Chobar ridge. Northern slope of the valley is composed of granite, gneiss and schist. These slopes are bounded by Kalphu fault in the north and Chandragiri fault in the south. Other slope of the valley and floor of the valley consist of metasediments. Therefore, sources of the basin-fill sediments are either metasediments zone or granite gneiss and schist to the north (Sakai 2001, Paudel 2004, 2008).

The valley was filled by material of the nearby hills. This basin-fill sediments are more than $500 \mathrm{~m}$ thick (Moribayashi and Mauro, 1980, Katel et al. 1996). From north came the fine sediments (sand and silt dominated), and that filled mostly northern half. These sediments are fluvio-deltaic origin (Sakai 2001, Dill et al. 2001). In the south, pebbly clay, conglomerate and diatomaceous earth are predominant. Peat clay and diatomaceous earth occurred in different parts but mostly in the central and southern parts of the valley. These sediments were broadly divided into three sedimentary facies: fluvio-deltaic in the north, fluvio-lacustrine in the south to center, alluvial fan and fluvial in the southern margin of the basin (Fig. 1b).

Sunakothi Formation is located above the muddy part of the Kalimati Formation, and covered by the terrace gravel deposits (Fig. 1). It is extensively distributed in the southern part of the Kathmandu Basin ranging in altitude from $\sim 1420 \mathrm{~m}$ in the southern margin to $1300 \mathrm{~m}$ in the central part of the basin. The type locality of this formation is at the Sunakothi, $3 \mathrm{~km}$ to the south of the Patan (Paudel and Sakai 2004). Well-exposed sub-type sections of this formation are exposed at the upstream of the Godawari Khola at Damaitar in the east, both side of the Nakhu Khola in the west, at the confluence between the tributary flowing from Dhapakhel and Kodkhu Khola, and Khayakadol Khola between Jorkhu and Parigaon at the southern most part of the Kathmandu Basin. The average thickness of this formation is 34 to $60 \mathrm{~m}$, and its thickness changes from south to the central part of the basin. The maximum thickness of this formation is exposed between the central and southern part of the basin where thick fluvial gravel is interbedded within the sandy and muddy sequence.

Lithology of this formation consists of massive to laminated, thick to thin bedded, gray to dark clay, silty clay, coarse to fine-grained sand with occasionally white diatomaceous silt, carbonaceous black clay and pebble to large boulder size gravels. The main sedimentary structures of this formation are large to small-scale cross-beddings, parallel and climbing ripple lamination, occasionally wavy ripple, trough and flasser lamination. Fine-grain sand and silt beds contain climbing ripple lamination, while the medium and coarse grain sand beds contain small to large-scale cross-beddings. Synsedimentary deformation structure such as dewatering structure,disc and pillar,convolute lamination, slump and distorated bedding, deformed sedimentary layers, and smallscale faulted structure are present within the sedimentary beds of this formation. Usually strike of the beds are running from NW to SE, and dip amount ranging from $4^{\circ}$ to $8^{\circ}$, and in some locality shows $12^{\circ}$. All the beds are dipping towards the north, and amount decreases toward the center of the basin.

\section{OVERVIEW OF DEFORMATION STRUCTURE}

Soft-sediments deformation structure (SSDS) are mainly considered to be part of the initial diagenetic changes of the sediments and include: slump structure which occurred on the slope like delta-front area, dewatering structures which occurred by the processes of upward escape of water commonly due to liquefaction and loading which occurred due to density contrasts between sand and underlying wet mud. Here, I present these structure on the basis of the following criteria:

(A) Structures produced by loading: Load structures are produced as a relatively dense bed sinks into the less dense beds. More dense beds are lying on top of the less dense beds. Density of any materials depends upon the porosity of the sediments. In some cases loading did not occur due to density inversion, in that case the sediments undergo liquefaction and deformation occurs. Load casts and flame structures are the example of this type (Fig. 2). Beside these structures pseudonodules, ball- and -pillow structure are other structures which are included within this types (Fig. 2).

(B) Deformation structures within individual sand beds: simple to complex folding of the individual beds are due to upward escape of water from individual beds, deformation of the cross-bedding are the characteristic of this types. Convolute lamination is intricate complex folding of laminae within the beds (Fig. 2). It occurs most commonly in fine sand to coarse silt. Generally, anticline crests are sharp relative to broad open syncline. Liquifaction is the main mechanism for the origin of such type of deformational structures.

(C) Dish-and-pillar, it is another types of structure which is originated due to upward escape of water (dewatering) during consolidation. During the water movement through sand, clay and organic matter is removed and redeposited produced dish structure which are generally dark layer and concave upward and vertical associated with dish is pillar (Fig. 2).

(D) Structure related to down slope gravity transport:various types of sedimentary structures are produced as a result of down slope gravity movement. Mostly, gravity folds (also known as slump folds) and gravity faults are example of this category.

(E) Structure related to sediments injections: They are caused by the injection of liquefied sand from below the ground surface (Fig. 2). 


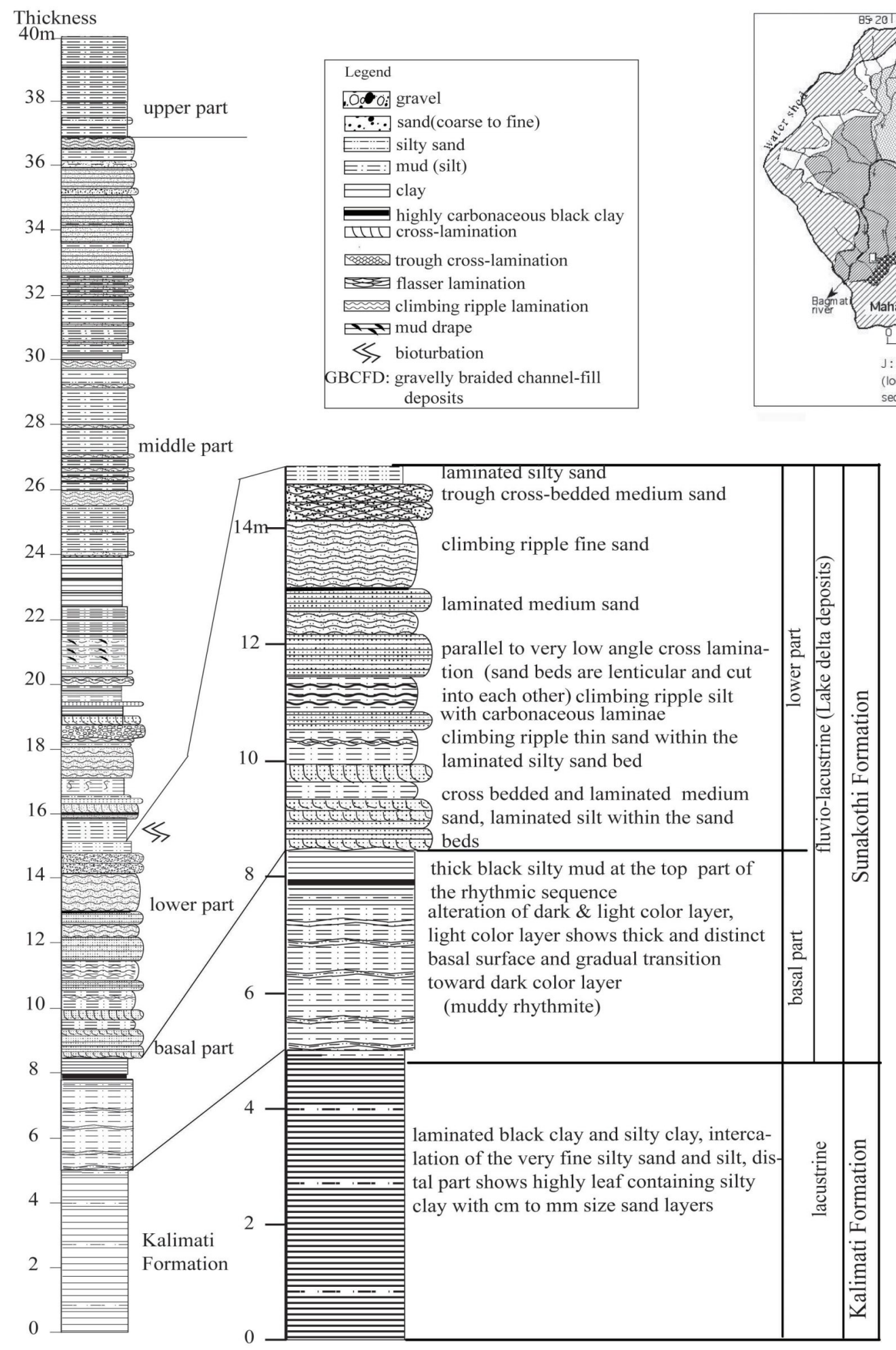

Fig. 1a: Complete stratigraphy of the southern part of the study area. Left side Fig. representative columnar section including soft sediment deformation structure measured from Sunakothi Formation. Right side shows detailed columnar section of basal and lower part 


\section{Load Structures}

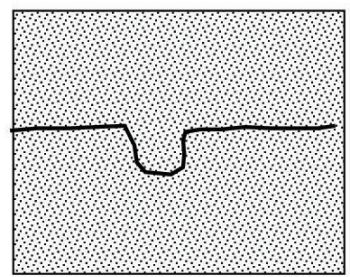

Simple loadcast

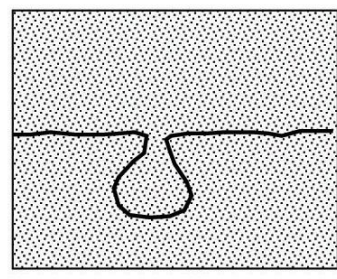

Pendulose loadcast

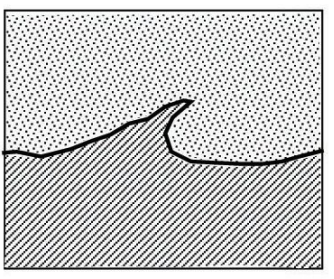

Flame structure

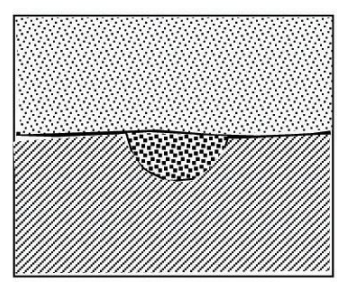

Attached Psudonodules

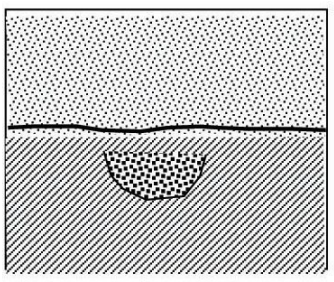

Detached Psudonodules

Water escape structure

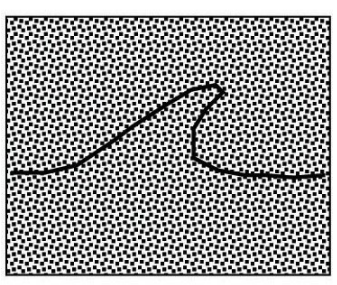

Water escape cusp

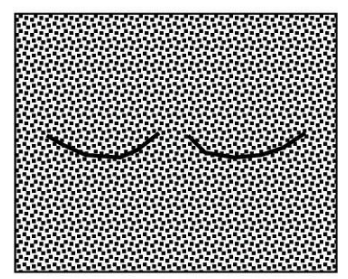

Dish and Pillars

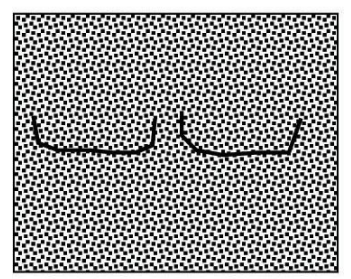

Pocket and Pillars

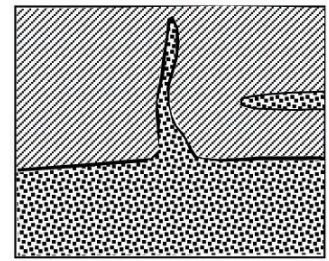

Dyke and Sill

Other structure

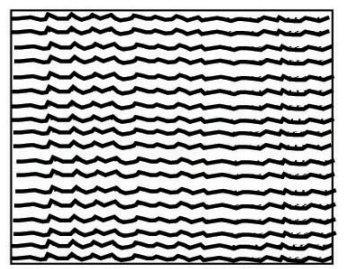

Disturbed laminites

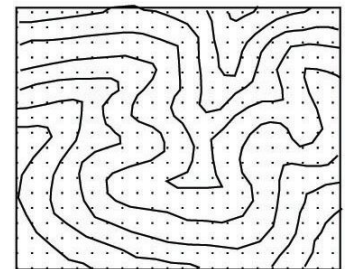

Convolute laminations

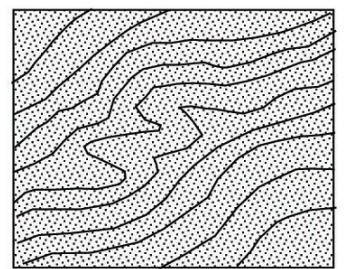

Slumping

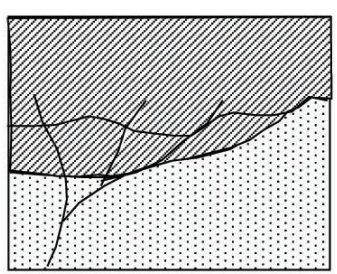

Synsedimentary faults

\section{Legends}
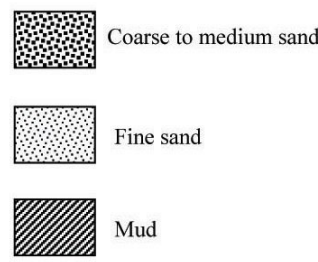

Fig. 2: Different patterns of the deformational structures originated by different mechanism within the sediments.

\section{TYPES OF DEFORMATION STRUCTURE IN THE STUDY AREA}

Various types of deformation structures are recorded within the Sunakothi Formation. Most of the deformational structures related to seismites. These structures occur both in marginal part and central part of the lake sediments (Fig. 1). Observed soft-sediments deformation structure in the study area are described under the following headings:

Load casts: These structures are frequently encountered mainly within the sandy and muddy strata. Owen (2003) have been proposed two types of load casts structure i.e. simple and Pendulous load casts. Both types of load casts were found within the Sunakothi Formation. They developed in diverse lithology, mostly medium and coarse sand overlying fine sand and silty clay. Overlying sand beds slightly penetrate into the underlying beds (Fig. 2 and 3). Laminations are slightly deformed to complex form (Fig. 3).

Another types of load casts is known as pendulous load casts which are developed in various types of lithology, mainly medium to coarse sand overlying on the silty sand and silty clay layers. Shape of the pendulous show various types. The internal lamination of the beds are deformed and some locations associated with convolute lamination.

Pseudonodules: It is elliptical or kidney shaped sand bodies which are formed by collapse into underlying mud. In some cases, this produces laterally continuous strings of isolated sand pods enveloped by muds. They are closely resemble a horizon of diagenetic concretions but texturally different from enclosing sediments (Fig. 3a). Three types of pseudonodules described by Own (2003). In this study area most frequently, attached pseudonodules are observing, others are detached which have been observed only in few loacations.

Flame structure: It is more larger than load casts structure. Own (2003) also called such types of structure as mud diapers. They are associated with load structures. Clay and silts beds are mostly affected by overlying sand beds (Fig. 4). In some beds antiflame structures are also identified. Generally, it shows curved wedge of the very fine silt beds and mud projected up between the sand lobes. Spacing between lobes is usually 2 to $10 \mathrm{~cm}$ but in some places may reach more. 

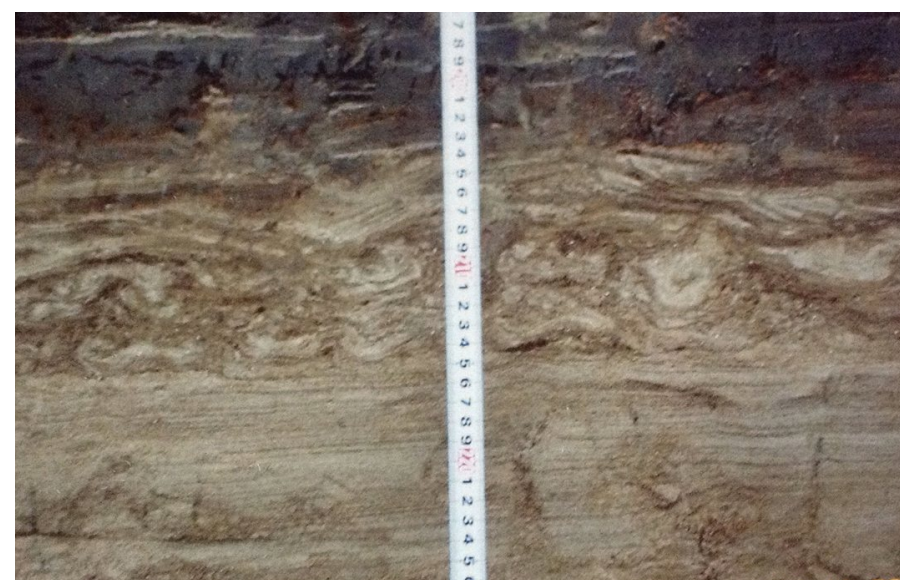

(a)

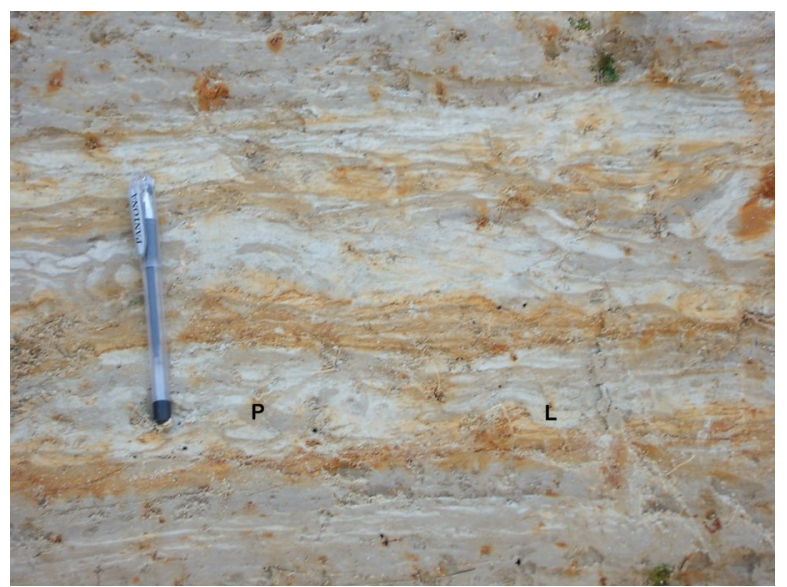

(b)

Fig. 3: Widely observed load structure seen in the study area mainly formed in medium to coarse sand (Pseudonodules (P), simple load (L) ) in fig. b)

\section{Water escape structures}

Convolute beds and lamination: it is characterized by complex, intricate folding of laminae within an undeformed beds of more or less uniform thickness. This types of structure

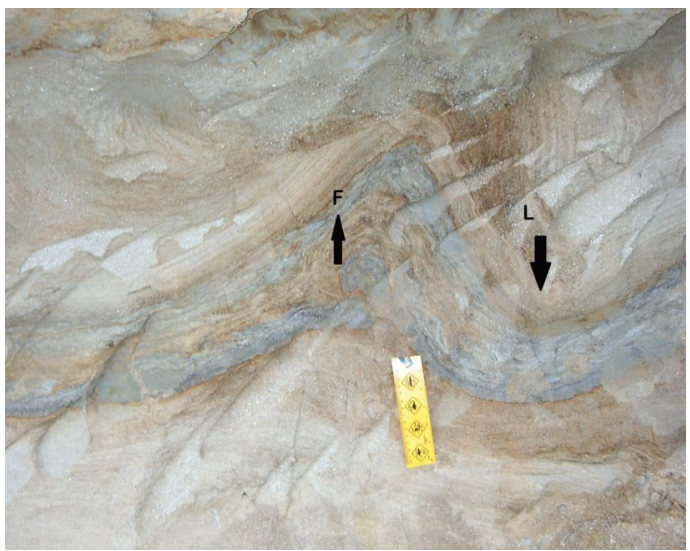

are developed in sand and coarse silt beds, which range in thickness from $25 \mathrm{~cm}$ to several decimenter. Folds are both anticline and syncline. Anticline crests are sharp in contrast to synclines, which are relatively broad and open (Fig. 4).

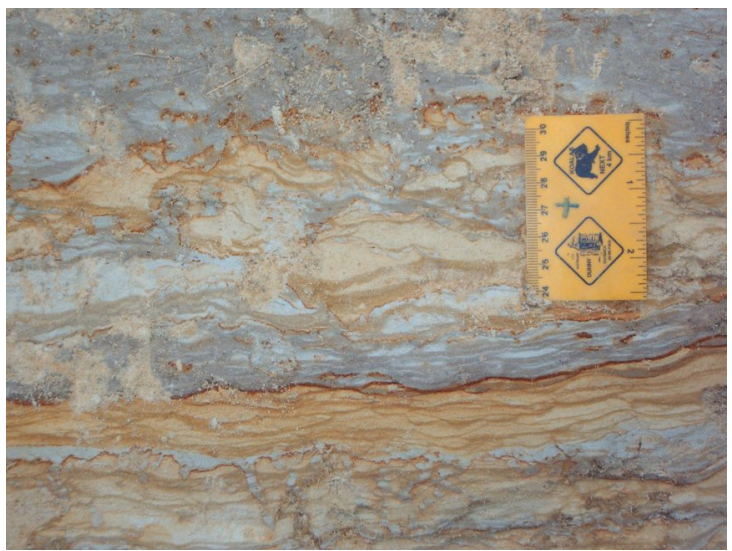

Fig. 4: Widely observed convolute structure seen in the study area mainly formed in medium to fine sand. F in the left side fig. is flame and $\mathrm{L}$ is load. Right side fig. shows dewatering structure with dish and pillar. Laminations are disturbed.

Dewatering structure: When sand liquefies, all preexisting structures are destroyed. If the liquefaction does not occur, only water escape upwards through the porous sediments. It can do it gently without displacing the grains or with a violent, in which case it entrains solid particles or deforms the sediments along its path (Fig. 4).

Dish- and -pillar structure: It is produced in rapidly deposited clay rich sand and silt by the upward escape of water (dewatering) during consolidation. Dish are dark colour pseudo-laminae formed by escaping water forced to follow horizontal flow path beneath semi-permeable laminae (Figs. 4 and 5). Thickness of dish is 0.2 to $4 \mathrm{~mm}$ size. These dark clay rich pseudolaminae are concave upward. Pillars are vertical structure associated with dish. Pillars served as conduits for verticle water movement. They are often associated with convolute bedding in thick sandstone beds.

Sand dikes: They are tabular, discordant sand bodies, which is few centimeter to few meter ( 1 to 2 meter). They are caused by the injection of liquefied sand from below sand beds (Fig. $5 b$ ). Internally sand shows very faint lamination (parallel to the contact with the host rock). In some location these sand injected as bedding-parallel sheet called sand sills. An uncommon variety of sand dike occurs as small, irregular and sinuous bodies formed when water saturated sand and mud beds are subjected to extension (Selley 1976). In this study area, the sand-filled fractures are commonly rooted in a sand bed and cut confining horizons of distinct lithologies. 


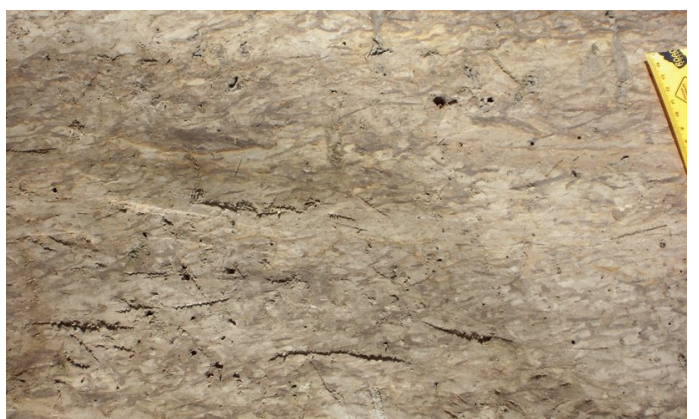

(a)

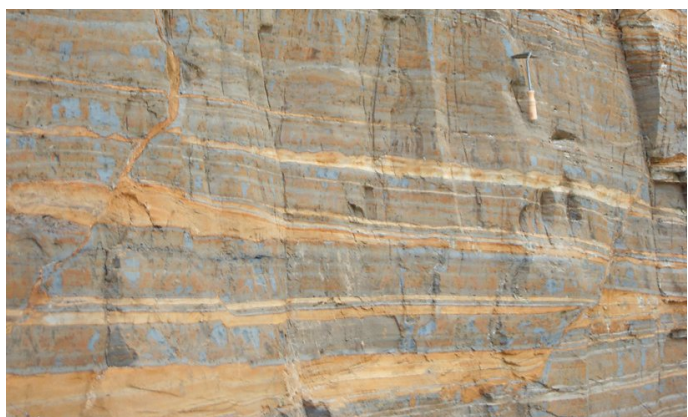

(b)

Fig. 5: Observed dish and pillar structure (a) structure seen in the study area mainly formed in medium to coarse sand, (b) shows the sand dyke invaded other beds.

Synsedimentary faults: The brittle behavior of the substances corresponds to cohesive nature of the soil, if increase in pore water pressure is not enough to liquefy the sediments. The presence of faults and their associated undeformed strata correspond to brittle deformation when sediments are either unconsolidated or partly consolidated

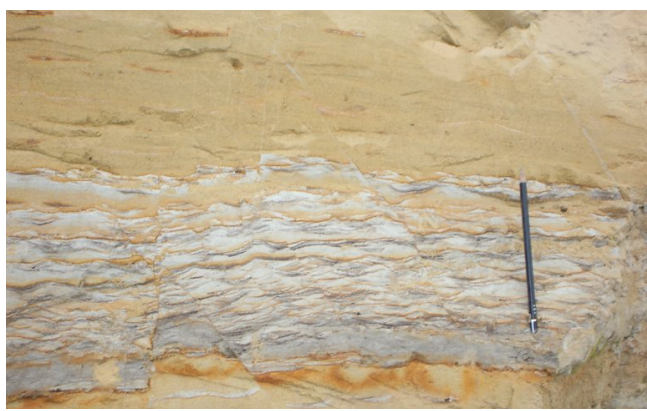

(a)
(Rossetti and Goes.2000). The sediments show the more compacted and less saturated have a brittle nature while the less compacted and more saturated sediments shows a ductile behaviour. In Sunakothi Formation such types of structure (Fig. 6) are observed in various locations within the study area.

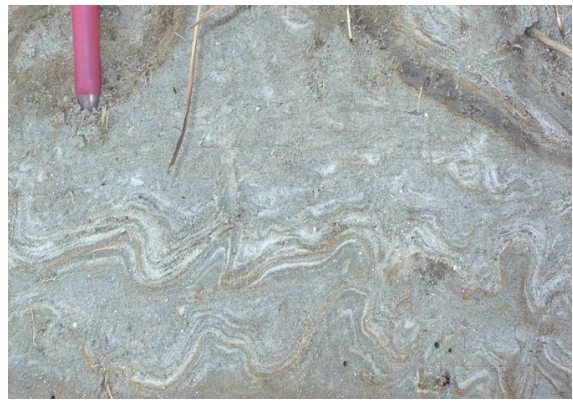

(b)

Fig. 6: Widely observed synsedimentary faults structure observed in the study area, mainly formed in medium to coarse sand (a), disturbed laminae and convolute lamination (b).

Mixed layers: Sedimentary beds show gradual upward tranisition from folded layers grading into various types of layers between undeformed beds (Fig. 5). According to Marco and Agnon (1995) such types of deformed beds are related to the activity of faults due to moderate to high magnitude seismic shocks. They are typically associated with varve-like, laminite units in which different horizons are differentiated from bottom to top are as follows: at the base undisturbed laminites is followed by folded layers of fine sand and silt, this folded layers is overlain by fracture layers followed by graded layers at the top.

Disturbed varved lamination: This structure developed in the laminated sequence of sand, silt and mud beds (Fig. 6). In some beds cross-bedded individual sets may show marked soft sediments deformation. The thickness of the disturbed lamine ranges from 1 to $10 \mathrm{~cm}$ with some change along the single beds. This types of deformational structure has been recognized mainly in Sunakothi sandy and muddy sequence. Such types of laminae show thinning and thikenning within the single beds (Fig. 6).

\section{DISCUSSION}

\section{Possible driving force for deformation}

Soft-sediment deformation structures are disruption of unconsolidated sedimentary strata (Mills 1983). This interpretation occurs in response to a deformation mechanism, a driving force and a triggering mechanism (Allen 1982, 1986, Owen 1987). The deformation mechanisms and driving forces have been reviewed by various authors (e.g., Allen, 1977, Lowe 1975, Mills 1983, Owen 1987, 2003 etc.). The sediments deformation occur before significant compaction of the sediments has taken place. Various driving forces can act simultaneously during deformation, so that in many cases there is no unique cause of deformation. In many cases, deformation mechanisms are initiated by an external agent, i.e. a triggering mechanism. Some of these mechanisms have been identified: artesian groundwater movement, earthquakes, storm currents and gravity flows (Owen 1987, 1996). Deformation mechanisms and driving force are interpreted below for each structure within this study area. 
Exposures of the Sunakothi Formation seismite on the southern part of the Kathmandubasin werefirst described within this paper. Gajurel et. al (1998) describe some deformation structure within the Kathmandu basin-fill sediments but from other sites commonly lack detail. Spectacular examples of slumping and soft-sediment deformation occur at many levels in the late Pleistocene Sunakothi Formation and Kalimati Formation. Synsedimentary fault movement, a potential trigger for soft-sediment deformation, is well documented throughout formations. The common characters which are observed in the study area are: all the beds within the same sequences are deformed, more or less structures are associated with vein filling, and most of the structures are not truncated.

Among describe above three factors: density and thickness of the beds involved and on the degree of their liquefaction. Most of the load structures are due to the liquefaction rather than only density contrast between below and top beds on the study area sequence. The force required is linked to lateral variations in the distribution of sediment load when the substrate is liquidized and loses its capacity to support overlying sediment. Individual sand and coarse silt beds show deformational structure mostly convolute bedding and lamination. Anticline crests of convolute laminations are more sharp in contrast to syncline which are relatively broad and open. The degree of deformation gradually decreases from bottom to top of the beds. This type of nature indicate liquefaction associated with rapid deposition is generally considered to be an important mechanism. Beside these other related factors may be expulsion of pore water, lateral laminar flow of the liquefied beds, shear caused by fluid flow acting on the sediments surface.

Dish and pillar structures are frequently encounter within the study area. Rapidly deposited clay-rich sand and coarse silt by upward escape of water (dewatering) during consolidation. Dish structures are dark colour pseudo-laminae formed by escaping water forced to follow horizontal flow paths beneath semi-permable laminae. As the water moves through the sand layer, clay and organic matter is removed and redeposited producing dish shape structure. The dark clay rich pseudolaminae are concave upward commonly penetrated the layer is pillars. Although there is no change in the thickness of disturbed laminites layers, flexural bending observed and interpreted as forming due to resistance against ductile deformation. Due to the resistance of ductile deformation individual layers (laminites) are bending.

The dikes exposed in the study area are generally developed as coarse-grained and medium sands intruding in silt and mud beds. The patterns of dikes are variable and their sizes are typically $20 \mathrm{~cm}$ to $1 \mathrm{~m}$. These structures are formed by intrusion of liquidized sands, interpreted as the result of liquefaction triggered by seismic shocks. The liquefaction is interpreted as resulting from water-saturated material with high pore water pressures moving upward.

Many synsedimentary faults (Fig. 7) observed within the study sequence. According to Owen (2011). brittle deformation of the beds corresponds to cohesive behavior, when increase in pore water pressure is not enough to liquefy sediments. Rossetti and G'oes (2000) pointed out that presence of these types of faults and their association with undeformed strata corresponds to a brittle deformation when sediments are either unconsolidated or partly consolidated.
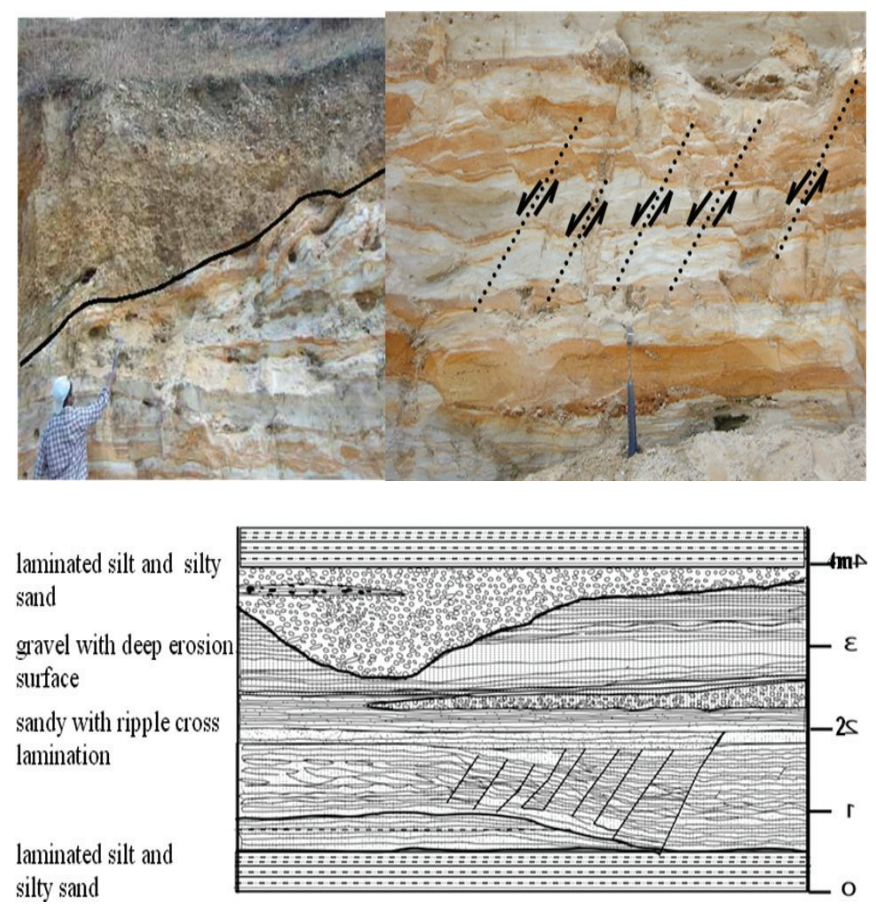

Fig. 7: Sunakothi sediments showing faulted sandy sequence within undisturbed lacustrine sediments

\section{Triggering mechanisms and draining of lake water}

There are various possible trigger mechanisms for soft-sediment deformation. The best known are (1) sediment loading (2) storm currents and (3) seismicity (G. Owen and M. Moretti 2011). Two groups of thought about the soft sediments deformation structure: (a) related to the mechanical state of the sediments at the time of deformation (b) large scale driving force required for deformation. They are mostly gravitational instability of the slope and seismic activity near the basin. Liquefaction is necessary for the mobilization of the previously deposited sediments whether in sedimentation or deformation processes. Considering sediment loading, the sudden excessive application of load due to irregular and rapid deposition on water-saturated sediments may constitute an affective triggering mechanism. Sediment loading appears to be of minor importance in the Sunakothi Formation, since I was unable to verify such large events of sediment transportation into the Kathmandu basin.

Storm currents can be a triggering mechanism but the deformation structures in the study area show no evidence for formation by such currents. In this study, seismicity is the most possible triggering mechanism that could have given rise to the forming soft-sediment deformation structures. This is because the Kathmandu basin is a seismically active intermontane 
basin with the large faults system are running near the basin that bound the basin. Kathmandu basin having generated earthquakes in the past and have played important roles in strata tilting during basin development. I interpret the softsediment deformation structures described from the Sunakothi formation to seismites, based on comparisons, shapes and dimensions in the field and experimental literature. Nature of the convolute lamination, dewatering structure, disc and piller, and others clearly support the origin must be liquefaction by seismicity. Historical earthquake data demonstrate that the area is seismically active. Seismic activity provide the surface shaking help to force the origin of soft sediments deformation was related to the gradual draining of the lake water.

\section{CONCLUSIONS}

The Kathmandu Basin is a seismically active intermontane basin where thick lacustrine sediments were deposited above the Kathmandu complex. In the southern part of the basin Lacustrine delta known as Sunakothi Formation composed mainly sand and mud. I describe for the first time soft-sediment deformation structures in coarse-grained sands, silt and mud beds. The deformation mechanisms and driving forces of these structures are compared with those known in the literature: load casts, clastic dikes and sills, disturbed laminae, convolute lamination, slump structures, and synsedimentary faults occurred due to density differences or uneven loading, injection of liquidized sands and pebbly sands, ductile deformation, gravitational instabilities associated with inverse density gradients, gravitational downslope movements, and brittle deformation, respectively. Regional geological data and field observations indicate that available triggering mechanism for the soft-sediment deformation structures is seismicity due to active faulting rather than deformation related to storm activity or sediment loading. This active faulting could provide the force for draining of the lake water.

\section{ACKNOWLEDGEMENTS}

I express my sincere gratitude to Prof. H. Sakai, Kyoto University Japan for his help in various matters. I extend acknowledge to Prof. B. N. Upreti, Prof. Dr. V. Dongol, Prof. Dr. T. N. Bhattarai, Dr. D. P. Adhikari and M. R. Manandhar and all members of the Department of Geology, Tribhuvaan University Nepal for their support in providing various suggestion and help.

\section{REFERENCES}

Allen, J. R. L., 1977, “The possible mechanics of convolute lamination in graded sand beds," Journal of the Geological Society, v. 134(1), pp. 19-31.

Allen, J. R. L., 1982, Sedimentary Structures: Their Character and Physical Basis, v.30 of Developments in Sedimentology, Elsevier, Amsterdam, The Netherlands.

Dill, H.G., Kharel, B. D., Singh, V. K., Piya. B., Busch, K. and Geyh, C., 2001, Sedimentology and paleogeographic evolution of the intermontane Kathmandu basin, Nepal, during the Pliocene and quaternary. Implication for formation of deposits of economic interest. Journal of Asian Earth Sciences, v. 19, pp.777-804.

Gajurel, A., Huyghe, P., France-Lanord., C,Mugnier, J. L., Upreti, B. N., and Le Fort P., 1998, Seismites in Kathmandu basin, in Nepal, Jour. Nepal Geol Soc., v. 18, pp. 125-134

Lowe, D. R., 1975, “Water escape structures in coarse grained sediments," Sedimentology, v. 22, pp. 157-204.

Marco, S.and Agnon,A., 1995, Prehistoric earthquake deformations near Massada, Dead Sea graben, Geology v. 23, pp 695-698.

Mills, P. C., 1983, "Genesis and diagnostic value of softsediment deformation structures-a review," Sedimentary Geology, v. 35, (2), pp. 83-104.

Owen, G., 1987, "Deformation processes in unconsolidated sands," in Deformation of Sediments and Sedimentary Rocks, M. E. Jones and R. M. F. Preston, Eds., v. 29, pp. 11-24,Geological Society of London.

Owen, G., 1996, "Experimental soft-sediment deformation: Structures formed by the liquefaction of unconsolidated sands and some ancient examples," Sedimentology, v. 43,(2), pp. 279-293.

Owen, G., 2003, "Load structures: gravity-driven sediment mobilization in the shallow subsurface," Geological Society Special Publication, v. 216, pp. 21-34.

Owen G. and Moretti, M., 2011, "Identifying triggers for liquefaction-induced soft-sediment deformation in sands," Sedimentary Geology, v. 235(3-4), pp.141147. View at Publisher - View at Google Scholar · View at Scopus

Paudel, M. R.,2014, Facies analysis of Sunakothi Formation, Kathmandu basin, Nepal and its significance Jour. Nepal Geol. Soc., v. 47, pp. 57-64.

Paudel, M. R. and Sakai, H.,2008, Stratigraphy and depositional environments of the basin-fill sediments in the southern marginal part of the Kathmandu Valley, central Nepal, Bulletin of the central Department of Geology, Tribhuvan University, Kathmandu, Nepal, v. 11, pp. 61-70.

Paudel, M. R and Sakai H., 2004, Stratigraphy and depositional environment of the basin-fill sediments in the southern part of the Kathmandu Valley, central Nepal, Abstract, the 111 Annual meeting of the Geological Society of Japan, pp 308.

Rossetti D. F. and G'oes, A.M., 2000, "Deciphering the sedimentological imprint of paleoseismic events: An example fromthe Aptian Codo Formation, northern Brazil," Sedimentary Geology, v. 135(1-4), pp. 137-156.

Rai, S. M., 2001, Geology, geochemistry, and radiochronology of the Kathmandu and Gosainkund Crystalline nappe, central Nepal Himalaya. Nepal. Jour. Nepal Geol. Soc. v. 25 (Sp. issue), pp. 135-155.

Sakai, H., 2001b, Stratigraphic division and sedimentary facies of the Kathmandu Basin sediments. Jour. Nepal Geol. Soc., v. 25 (Sp. Issue), pp.19-32

Stocklin, J. and Bhattari, K.D., 1981, Geology of the Kathmandu area and central Mahabharat Range, Nepal Himalayas. HMG Nepal/UNDP report, 64p. 